\title{
Ecology and conservation of the Mediterranean trout in the central Apennines (Italy)
}

\author{
Massimo LORENZONI, ${ }^{1}$ Antonella CAROSI,${ }^{1 *}$ Massimo GIOVANNOTTI, ${ }^{2}$ Gianandrea LA PORTA, ${ }^{1}$ \\ Andrea SPLENDIANI, ${ }^{2}$ Vincenzo CAPUTO BARUCCHI ${ }^{2}$ \\ ${ }^{1}$ Department of Chemistry, Biology and Biotechnologies, University of Perugia, via Elce di Sotto, Perugia; ${ }^{2}$ DiSVA, Università \\ Politecnica delle Marche, via delle Brecce Bianche, Ancona, Italy
}

\begin{abstract}
The Mediterranean brown trout is one of the freshwater fish species complex at greater risk of extinction in the Mediterranean area. The introduction of alien invasive species and their interaction with the native fauna represent some of the major threats to the survival of this species. Currently, the genetic variability of the Mediterranean trout is being compromised by the introgressive hybridization with the Atlantic trout (Salmo trutta Linnaeus, 1758). Therefore, it is necessary to gain further knowledge on genetic and demographic characteristics of Mediterranean trout populations, that, combined with environmental and angling data, will allow to undertake sound conservation strategies. The aims of the present study were to analyze: i) the demographic characteristics of the Mediterranean trout in seven central Apennine river basins where native populations are threatened by stocking with the domestic trout of north Atlantic origin; ii) the influence of both environmental parameters and different fishery management strategies on the status of native trout populations. The project focuses on 14 sites included in the Natura 2000 EU wide network of nature protection areas, established under the 1992 Habitat Directive. A total of 25 watercourses were investigated for a total of 32 sampling sites. A census of the fish fauna was carried out by electrofishing at each sampling location. Fish and environmental data were collected in spring and autumn 2014. The results obtained in the present research allowed us to detect the presence of three residual Mediterranean trout populations with a high degree of genetic integrity in the study area. The native trout populations were characterized by higher abundances and higher adult density values. Well-structured native populations with higher legal-size specimens density and poor body conditions in terms of relative weight were observed in the no-fishing areas, probably due to the presence of intraspecific competition phenomena. The environmental analysis confirmed the key role played by the geological characteristics of the central Apennines in shaping the introgression levels observed in the wild trout populations, while the recovery of the water quality appears decisive in the development of management strategies aimed at their conservation.
\end{abstract}

\section{INTRODUCTION}

The Mediterranean trout (Salmo trutta complex) is one of the freshwater fish species at greater risk of extinction in the brown area. This taxon is represented by a wideranging species complex native to Eurasia and North Africa (Elliot, 1994) and includes the surviving native populations of the Tyrrhenian and Adriatic side of the

Corresponding author: antonella.carosi@unipg.it

Key words: Mediterranean river basin, native trout, demographic characteristics, environmental features, biodiversity conservation.

Edited by: Pietro Volta, CNR-IRSA, Italy

Received: 13 March 2018.

Accepted: 12 September 2018.

This work is licensed under a Creative Commons Attribution NonCommercial 4.0 License (CC BY-NC 4.0).

(C) Copyright M. Lorenzoni et al., 2018

Licensee PAGEPress, Italy

J. Limnol., 2019; 78(1): 1-13

DOI: 10.4081/jlimnol.2018.1806
Italian peninsula. In the last decade the wild populations have declined by almost $30 \%$ and this trend is also expected for the future (Caputo et al., 2015). Water abstraction, overfishing, non-native trout diffusion (Clavero et al., 2010) and reduction of suitable brown trout thermal habitats in the Mediterranean basin (Almodóvar et al., 2012; Filipe et al., 2013) represent the most important threats to the future conservation of the Mediterranean trout (IUCN, 2018). In addition, climate changes will lead to a worsening of the ecological conditions (in terms of hydrological instability and heterogeneity) of the Mediterranean region watercourses, already particularly vulnerable to the reduced availability of water (Almodóvar et al., 2012; Lorenzoni et al., 2014; Larios-López et al., 2015). As the taxonomy of the genus Salmo in Italy is still controversial, in the present paper the terms "Mediterranean trout" and "native brown trout" for the native brown trout were used. The scientific name Salmo trutta Linnaeus, 1758 was used to identify the alien brown trout of Atlantic origin. In the IUCN red list (IUCN, 2018) the Mediterranean trout is referred to Salmo cettii Rafinesque, 1810.

Currently, the genetic integrity of the Mediterranean trout is being compromised by the introgressive hybridization with the alien $S$. trutta (Nonnis Marzano et al., 2003; Caputo et al., 2004; Lorenzoni et al., 2004; Sanz 
et al., 2006). Stocking programs carried out in the last century with domestic trout is resulting in the loss of native genetic variability, even though several evidences indicated a surprising resilience of native brown trout genetic diversity probably related to: i) their adaptation to the hydrogeological characteristics of the calcareous and permeable catchments in central Apennine, and ii) their demographic characteristics (in terms of high abundances), so the stocking efforts were not enough to replace them (Splendiani et al., 2013, 2016). These latter studies, however, explored the role of environmental variables on a broad scale, based on literature data, because the local environmental characteristics were unavailable. On the contrary, in the present study, a suite of local environmental parameters were collected in the field and included in a multivariate statistical framework. According to several authors (Aparicio et al., 2000; Solomon et al., 2003; Almodovar et al., 2006) the rational conservation and management programs involving salmonid species implicates important socio-economic interests and should be based on sound objective data, with the aim to support both sustainable fisheries and genetic biodiversity conservation. Many studies carried out in the Mediterranean area, dealing with the relationship between alien genes abundance and management of trout populations (García-Marín et al., 1998, 1999; Mezzera and Lagardier, 2001) highlighted the need to dispose of a deep knowledge of genetic and demographic characteristics of the trout populations, which combined with environmental and angling data, allow to undertake sound conservation strategies. Therefore, the aims of the present research were: i) to elucidate the mechanism underling the resilience of native genome in some circumstances, and the spread of introgression phenomena in some others, and ii) to analyze the influence of environmental parameters and fishery management on the status of trout populations, focusing on the ecological preferences of the Mediterranean trout.

\section{METHODS}

\section{Study area}

The project focuses on 14 sites included in the Natura 2000 EU wide network of nature protection areas, established under the 1992 Habitat Directive (Fig. 1) and involved also the territory of Sibillini Mountains National Park. The study area comprises seven watersheds: Metauro, Cesano, Esino, Potenza, Chienti, Tevere and Tenna. A total of 25 watercourses were investigated with 32 sampling sites (Tab. S1). Fish data were collected in two periods (spring and autumn 2014), while hydrological variables were measured three times during the year 2014: spring, summer and autumn.

\section{Data collection}

A census of the fish fauna was carried out at each sampling location by multiple-pass electrofishing using the removal method (Moran, 1951; Zippin, 1956). The method provided the sampling of the same river stretch (starting from downstream to upstream) for two or more consecutive times, applying the same fishing effort (Seber and Le Cren, 1967). For each specimen caught, total length and weight was measured and a sample of scales was collected for age determination. An adipose fin clip was removed from 734 trout specimens, previously anesthetized, and preserved in 95\% ethanol until DNA extraction. All scales were stored in 33\% ethanol and later observed with a stereo microscope using the imageanalysis system IAS 2000. At the end of the field activities, all the fish caught were released in the rivers. Age was determined using the scalimetric method (Bagenal, 1978) and further validated through the analysis of the length-frequency distribution (Britton et al., 2004). All specimens with age $\geq 2^{+}$were considered adults. For all the specimens the species status was determined according to the genetic characterization. For each population the individuals were counted in order to determine the abundance, in terms of density (ind $\mathrm{m}^{-2}$ ) and standing crop $\left(\mathrm{g} \mathrm{m}^{-2}\right)$. The standing crop was calculated by multiplying the estimated population size by the mean weight of the fish caught (breaking down the total sample for age classes), and then dividing the result by the sampling area (Zippin, 1956). In order to characterize the sampling sites 19 environmental parameters that play a crucial role in the distribution and life-history strategies of freshwater fish species were selected (Vadas and Orth, 2000; Smith and Kraft, 2005) (Tab. 1). Watershed area, distance to water source, average slope and altitude were derived from digital maps (GIS). The soil permeability was determined from the Italian geo-lithological map 1:500000 (WMS Service pcn.minambiente.it). The flow rate was measured at the cross-sectional area of each sampling reach, according to the guidelines of Standard ISO 748:2007, using an OTT MF-pro electromagnetic current meter. $\Delta$ flow rates were calculated as the differences between the measurements carried out in the different seasons ( $\Delta 1$ spring-summer, $\Delta 2$ summer-autumn). Field measurements of specific conductivity, $\mathrm{pH}$, water temperature and dissolved oxygen were carried out with electronic meters manufactured by YSI (Hanna Instruments) and WTW ( $\mathrm{GmbH})$. Other chemical parameters of the water (dissolved oxygen, $\mathrm{NNO}_{3}, \mathrm{NNH}_{3}, \mathrm{SO}_{4}, \mathrm{PPO}_{4}, \mathrm{Cl}, \mathrm{COD}$ ) were determined according to the National Agency for Environmental Protection and Technical Services (APAT) specifications (APAT, 2003). Given the importance of the physical instream habitat in affecting the structure of the fish assemblages (Lammert and Allan, 1999), canopy cover 
and shaded areas were estimated by visual observation on a five-degree scale $(0=$ absent, $1=$ isolated areas, $2=$ frequent interruptions, $3=$ few interruptions and $4=$ continuous areas). The environmental variables were measured at the same time as fish sampling.

\section{Genetic analyses}

\section{Sampling and genomic DNA extraction}

Total DNA was extracted from adipose fin clips preserved in $95 \%$ ethanol (see above) by using a MagCore $\AA$ automated Nucleic Acid extractor. After purification, DNA

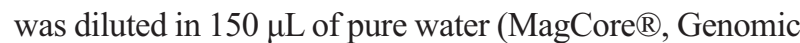
DNA Tissue Kit, $\mathrm{n}^{\circ}$ 401) and quantified using a NanoDrop spectrophotometer (ThermoScientific).

\section{mtDNA sequencing}

After DNA extraction, the mtDNA control region (Dloop) was amplified by polymerase chain reaction (PCR) using the primers LN20 (5'-ACCACTAGCA CCCAAAGCTA-3') and HN20 (5'-GTGTTATGCTTTA GTTAAGC-3') (Suarez et al., 2001). The amplification was performed for each sample in a $25-\mu \mathrm{L}$ PCR reaction

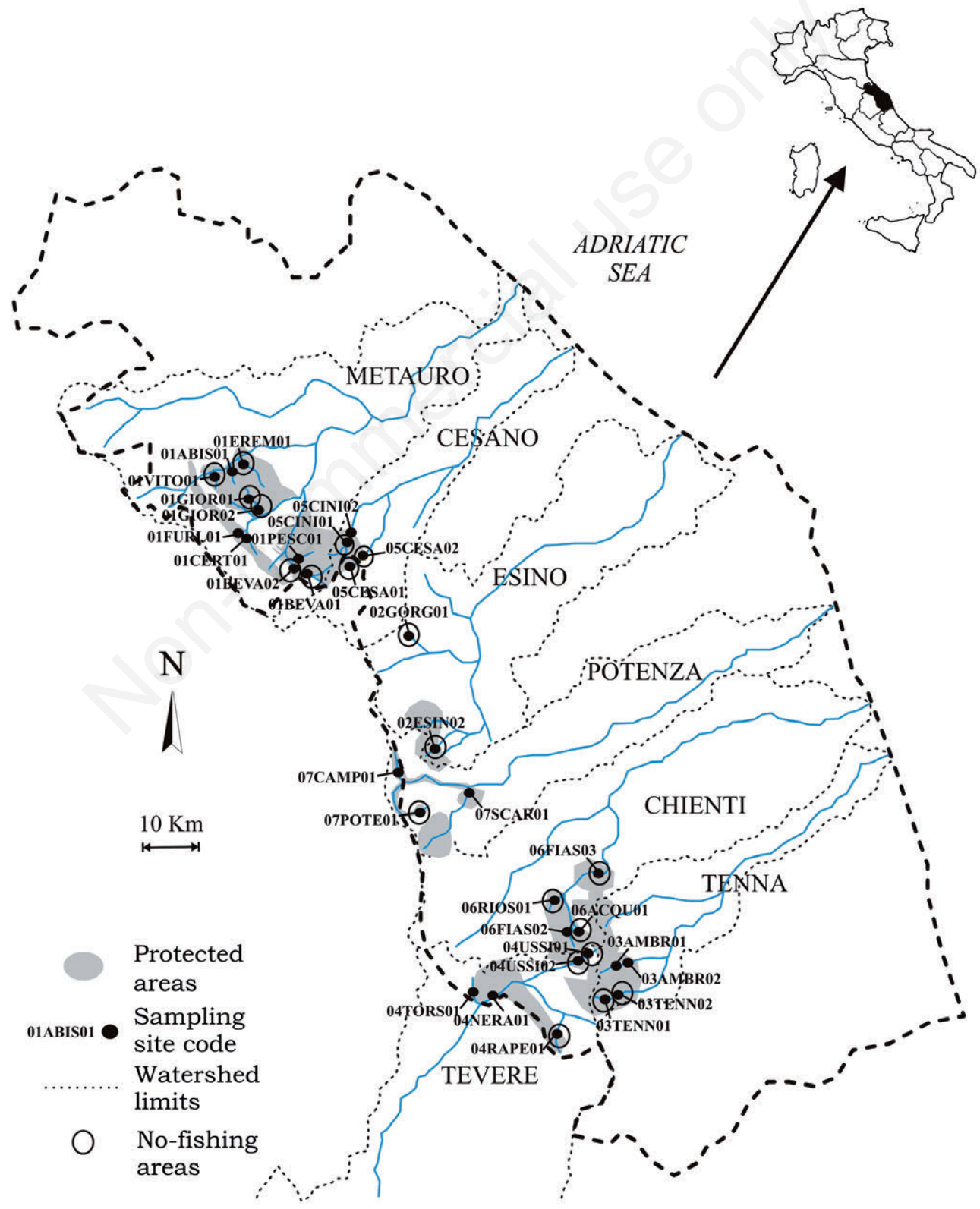

Fig. 1. Study area and location of the sampling sites. 
containing: 1X MyTaq (Bioline) reaction buffer, $0.4 \mu \mathrm{M}$ of each primer, $1.5 \mathrm{U}$ myTaqTM DNA polymerase (Bioline) and $3 \mu \mathrm{L}$ of DNA $(\sim 40 \mathrm{ng} / \mu \mathrm{L})$. Cycling conditions required an initial denaturation at $94^{\circ} \mathrm{C}$ for $5 \mathrm{~min}$, followed by 35 cycles of $94^{\circ} \mathrm{C}$ for $60 \mathrm{~s}, 55^{\circ} \mathrm{C}$ for $60 \mathrm{~s}$ and $72^{\circ} \mathrm{C}$ for $60 \mathrm{~s}$, with a final extension step at $72^{\circ} \mathrm{C}$ for $5 \mathrm{~min}$. All PCR products were visualised on a $2 \%$ agarose gel stained with Gel RedTM (Biotium, Inc.) to evaluate amplification success, and digested at $37^{\circ} \mathrm{C}$ overnight using the restriction enzyme AluI in a $20-\mu \mathrm{L}$ reaction containing $1 \mathrm{X}$ Tango Buffer, $7 \mathrm{U}$ AluI and $2 \mu \mathrm{L}$ of PCR product. The digestion step was crucial to reduce the size of the amplicons and as a consequence to improve the resolution power of the successive Single-Strand Conformation Polymorphism (SSCP) analysis. The restriction enzyme AluI was chosen on the basis of the result obtained in previous studies (e.g., Dovc et al. 2004). The following step was a SSCP analysis, which required the run of the digested products on a nondenaturing $8 \%$ polyacrylamide gel and successive visualisation by silver staining protocol (Benbouza et al., 2006). One sample (or, when possible, three) for each SSCP haplotype obtained was purified with the ExoSAP-it KIT and Sanger sequenced with the reverse primers $\mathrm{H} 2$ (Bernatchez and Danzmann, 1993) on an ABIPRISM 3730XL DNA sequencer.
All obtained partial D-loop sequences were aligned using the software ClustalW v. 1.8 (Thompson et al., 1994) with haplotypes previously described for this species. The attribution of our sequence haplotypes to each of the main brown trout lineages, previously described, was performed based on the diagnostic sites characterising the main brown trout mtDNA lineages.

\section{LDH-C1* locus polymorphism}

The occurrence of introgression was also evaluated through the PCR-RFLP analysis of a portion of the nuclear locus LDH-C1* (as described in McMeel et al., 2001). This marker discriminates European hatchery stocks (fixed for the $* 90$ allele or with very high frequency of this allele) from the native Mediterranean populations, characterized by the $* 100$ allele (McMeel et al., 2001).

\section{Statistical treatment of mtDNA data}

The control region sequences were aligned with the data set described by Bernatchez (2001) using CLUSTALW (Larkin et al., 2007). The attribution of sequence haplotypes obtained in the present study to each of the main brown trout lineages (see Bernatchez, 2001) was performed

Tab. 1. Canonical and correlation coefficients of environmental variables with axis. $\mathrm{P}<0.05$ is in bold.

\begin{tabular}{|c|c|c|c|c|c|c|}
\hline \multirow[b]{2}{*}{ Environmental and genetic parameters } & \multicolumn{2}{|c|}{ Canonical coefficients } & \multicolumn{4}{|c|}{ Correlations with axis } \\
\hline & $\mathbf{A X} 1$ & $\mathbf{A X} 2$ & $\mathbf{A X} 1$ & $\mathbf{P}$ & $\mathbf{A X} 2$ & $\mathbf{P}$ \\
\hline Watershed area $\left(\mathrm{km}^{2}\right)$ & 1.749 & -0.823 & -0.079 & 0.548 & -0.198 & 0.130 \\
\hline Distance to water source $(\mathrm{km})$ & -1.495 & 1.048 & -0.121 & 0.358 & 0.007 & 0.960 \\
\hline Average slope $(\%)$ & 0.679 & 0.452 & -0.026 & 0.845 & 0.409 & 0.001 \\
\hline Altitude (m a.s.l.) & -1.156 & -0.068 & -0.413 & 0.001 & 0.160 & 0.222 \\
\hline Flow rate $\left(\mathrm{m}^{3} \cdot \mathrm{s}^{-1}\right)$ & 0.136 & 0.130 & 0.191 & 0.143 & -0.012 & 0.928 \\
\hline$\Delta$ flow rate $\left(\mathrm{m}^{3} \cdot \mathrm{s}^{-1}\right)$ & -0.416 & -0.020 & 0.054 & 0.682 & -0.258 & 0.047 \\
\hline Permeability (units) & -0.193 & 0.094 & -0.200 & 0.126 & 0.276 & 0.033 \\
\hline Canopy cover (units) & 0.131 & -0.733 & -0.091 & 0.489 & -0.343 & 0.007 \\
\hline Average shaded surface (units) & -0.212 & -0.213 & -0.187 & 0.154 & -0.150 & 0.253 \\
\hline Water temperature $\left({ }^{\circ} \mathrm{C}\right)$ & -0.693 & -0.136 & -0.100 & 0.154 & -0.398 & 0.002 \\
\hline $\mathrm{pH}$ (units) & -0.033 & 0.186 & 0.154 & 0.240 & 0.145 & 0.001 \\
\hline Conductivity $\left(\mu \mathrm{S} \cdot \mathrm{cm}^{-1}\right)$ & -0.101 & 0.163 & 0.396 & 0.002 & -0.137 & 0.298 \\
\hline Dissolved oxygen $\left(\mathrm{mg} \cdot \mathrm{L}^{-1}\right)$ & 0.408 & 0.429 & -0.104 & 0.430 & 0.348 & 0.007 \\
\hline $\mathrm{NNO}_{3}\left(\mathrm{mg} \cdot \mathrm{L}^{-1}\right)$ & -0.003 & -0.192 & -0.025 & 0.849 & -0.042 & 0.750 \\
\hline $\mathrm{NNH}_{3}\left(\mathrm{mg} \cdot \mathrm{L}^{-1}\right)$ & -0.113 & 0.001 & -0.082 & 0.535 & -0.153 & 0.242 \\
\hline $\mathrm{SO}_{4}\left(\mathrm{mg} \cdot \mathrm{L}^{-1}\right)$ & 0.402 & 0.040 & 0.458 & 0.001 & -0.186 & 0.156 \\
\hline $\mathrm{PPO}_{4}\left(\mathrm{mg} \cdot \mathrm{L}^{-1}\right)$ & -0.125 & 0.030 & -0.254 & 0.051 & -0.256 & 0.048 \\
\hline $\mathrm{Cl}\left(\mathrm{mg} \cdot \mathrm{L}^{-1}\right)$ & 0.172 & -0.218 & 0.233 & 0.073 & -0.053 & 0.689 \\
\hline $\mathrm{COD}\left(\mathrm{mg} \cdot \mathrm{L}^{-1}\right)$ & -0.024 & -0.123 & 0.113 & 0.390 & -0.207 & 0.112 \\
\hline Alien genome & -2.014 & 3.587 & 0.347 & 0.007 & -0.213 & 0.103 \\
\hline Native genome & -2.499 & 3.872 & -0.334 & 0.009 & 0.224 & 0.086 \\
\hline
\end{tabular}


based on the diagnostic sites characterising these lineages. The assessment of genetic introgression at mtDNA level was based directly from the frequency of the domestic Atlantic haplotypes observed in the wild samples.

\section{Statistical treatment of LDH-C1* data}

The PCR-RFLP analysis of $\mathrm{LDH}-\mathrm{Cl}{ }^{*}$ locus was used to estimate the spread of the allochthonous $* 90$ allele in the area. Deviation from Hardy-Weinberg equilibrium (HWE) was evaluated by Weir and Cockeram (1984) F statistic (FIS) using GENEPOP 4.0 (Raymond and Rousset, 1995). The exact FIS P-values were obtained implementing a Markov chain method based on 1000 dememorizations, 1000 batches and 10000 iterations per batch.

\section{Data analysis}

Based on the results of genetic analyses performed using mitochondrial (D-loop fragment of $310 \mathrm{bp}$ ) and nuclear markers (locus $\mathrm{LDH}-\mathrm{Cl}{ }^{*}$ ) (Caputo et al., 2015), the $t$-test analysis was performed to compare the demographic characteristics of native and non-native trout populations.

To investigate the effects of different management strategies on the genetic and demographic characteristics of the Mediterranean trout populations, the sampling sites were divided into fishing and no-fishing areas (Fig. 1). The $t$-test analysis was performed to compare the demographic characteristics in these different areas.

To provide a numeric estimation for deviations of the population structure from a balanced population, the Proportional Stock Density (PSD) index (Gabelhouse, 1984) was calculated as follows:

$$
\begin{gathered}
\mathrm{PSD}=100 \text { (number of fish } \geq \text { minimum quality length/ } \\
\text { number of fish } \geq \text { minimum stock length) }
\end{gathered}
$$

For minimum quality length and minimum stock length were used the values indicated by Pedicillo et al. (2010) for the trout populations of central Italy. The PSD values vary from 0 to 100 and the defined range for a balanced population is: $35 \leq \mathrm{PSD} \leq 65$ (Gabelhouse, 1984; Gassner et al., 2003).

As a contribution to the evaluation of the fish-health, the relative weight $\left(\mathrm{W}_{\mathrm{r}}\right)$ was estimated on the basis of the equation $\mathrm{W}_{\mathrm{r}}=100 \mathrm{~W} / \mathrm{W}_{\mathrm{s}}$, where $\mathrm{W}$ is the weight of the individual and $\mathrm{W}_{\mathrm{s}}$ is the standard weight calculated by the following equation proposed for the brown trout, applying the Empirical Percentile (EmP) method (Angeli et al., 2009):

$$
\log _{10} \mathrm{~W}_{\mathrm{s}}=-5.203+\left(3.154 \log _{10} \mathrm{TL}\right)-\left(0.015\left(\log _{10} \mathrm{TL}\right)^{2}\right)
$$

Wr values lower than 95 indicate poor body condition (Blackwell et al., 2000). Only specimens with TL $>8 \mathrm{~cm}$ were included in the analysis (Angeli et al., 2009). In order to avoid biases in the $\mathrm{Wr}$ statistical analysis, the comparison between the subsample of genetically analyzed specimens $(n=704)$ with the total sample composed of all the trout collected was carried out using $t$-test analysis $(\mathrm{t}=0.96 ; \mathrm{P}=0.326)$.

Genetic and demographic parameters were related to the environmental variables by means of canonical correspondence analysis (CCA) (ter Braak, 1986), that is a direct gradient analysis method that allows the examination of the relationships among multivariate ecological data matrices. Statistical significance was tested with Monte Carlo permutation tests (1000 permutations). In order to avoid collinearity, for each population 2 genetic parameters were used, calculated as the mean value of ATs 1 and $L D H-C 1 * 90$ data (alien genome) and the mean value of $\mathrm{AD}+\mathrm{MA}+\mathrm{ME}$ and $L D H$ $C 1^{*} 100$ data (native genome). The demographic matrix included $\mathrm{W}_{\mathrm{r}}, \mathrm{PSD}$, five abundance parameters (population density, adult density, young-of-the-year (YOY) and specimens of legal size (TL $>22 \mathrm{~cm}$ ) densities and standing crop) and 64 observations (32 sampling sites $\mathrm{x} 2$ census periods). The environmental matrix included 23 variables (19 environmental and 2 genetic parameters) and 64 observations. All variables used in the analysis were tested for normality and transformed $\left(\log _{10}(\mathrm{~N}+1)\right)$ to normalize the distribution (Brown and Austen, 1996).

\section{RESULTS}

\section{Genetic characterization}

\section{$m t D N A$}

Overall, sequence analysis revealed 4 different D-loop haplotypes already described in literature (Bernatchez 2001; Splendiani et al., 2006). In details, we observed the haplotype ATs1 (Atlantic lineage, sensu Bernatchez), a haplotype very common in the rivers from North Europe and in domestic stocks, the haplotype ADs7 (AD lineage) mainly distributed along the peri-Adriatic and Ionian rivers (Apostolidis et al., 1997; Splendiani et al., 2006), the haplotype MAs5, until now exclusively found in central Italy (Splendiani et al., 2006) and the haplotype MEs1, very common in Mediterranean rivers (Cortey et al., 2004). At single population level, the exclusive presence of the ATs1 haplotype was observed in 13 out of 32 wild populations. Conversely, in four local samples (03AMBR01, 03AMBR02, 04TORS01, 04NERA01) the alien haplotype ATs1 was not observed. In the rest of the wild samples the percentage of ATs 1 ranged from $5 \%$ in 03TENN02 to $72.7 \%$ in 07SCAR02 (Tab. 2). 


\section{$\mathrm{LDH}-\mathrm{Cl}$ *}

The introgression patterns detected with the $\mathrm{LDH}-\mathrm{Cl}$ * locus identified the presence of 14 Atlantic populations, 2 Mediterranean populations and 16 partially introgressed populations, with percentage of $\mathrm{LDH}-\mathrm{C} 1 * 90$ comprised between $11 \%$ and $82 \%$ (Fig. 2). The comparison of these results with the mtDNA haplotypes showed a high and significant correlation (Spearman's $r s=0.83, \mathrm{P}<0.001$ ). However, discrepancy was detected between the presence of the allele $* 90$ and AT haplotypes in some of the populations studied (Tab. S1). The observed genotype frequencies at this locus did not showed significant departures from Hardy-Weinberg proportions.

\section{Demographic characterization}

A total of 4405 specimens of trout were collected. The size of the total sampled fish ranged from 2.7 to $50.0 \mathrm{~cm}$ (mean $\pm \mathrm{SE}=13.52 \pm 0.16$ ) and weight from 0.7 to $1325.0 \mathrm{~g}$ $\mathrm{cm}(\operatorname{mean} \pm \mathrm{SE}=50.61 \pm 2.63)$. Ten age classes $\left(0^{+}\right.$to $\left.9^{+}\right)$were identified. Based on the genetic characterization the total sample was divided into three categories: i) "low introgressed" population, as the frequency of Atlantic variants (mtDNA and $\mathrm{LDH}-\mathrm{Cl}$ * locus) were below $10 \%$ for the mtDNA and below $20 \%$ for the $\mathrm{LDH}-\mathrm{Cl}$ * locus, ii) "severe introgressed" population, as the frequency of Atlantic variants was above $90 \%$ for the mtDNA and above $80 \%$ for the $\mathrm{LDH}-\mathrm{Cl}{ }^{*}$ locus, and iii) all the remaining

Tab. 2. Allele ( $\mathrm{LDH}-\mathrm{C} 1^{*}$ locus) and haplotype (D-loop, mtDNA) and frequencies for 32 central Italy wild samples.

\begin{tabular}{|c|c|c|c|c|c|c|}
\hline Sampling site code & $L D H-C 1 * 90$ & $L D H-C 1 * 100$ & $A T s 1$ & $A D s 7$ & MAs5 & MEsI \\
\hline 01ABIS01 & 100.0 & & 100.0 & 6 & & \\
\hline 01BEVA01 & 79.6 & 20.4 & 100.0 & 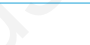 & & \\
\hline 01BEVA02 & 68.2 & 31.8 & 72.2 & & 27.8 & \\
\hline 01CERT01 & 96.0 & 4.0 & 30.0 & 70.0 & & \\
\hline 01EREM01 & 87.5 & 12.5 & 100.0 & & & \\
\hline 01FURL01 & 100.0 & & 100.0 & & & \\
\hline 01GIOR01 & 83.3 & 16.7 & 33.3 & 66.7 & & \\
\hline 01GIOR02 & 80.8 & 19.2 & 15.4 & 84.6 & & \\
\hline 01PESC01 & 100.0 & 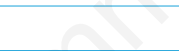 & 100.0 & & & \\
\hline 01VITO01 & 79.7 & 20.3 & 100.0 & & & \\
\hline 02ESIN02 & 53.7 & 46.3 & 15.0 & 45.0 & 40.0 & \\
\hline 02GORG01 & 95.8 & 4.2 & 70.0 & 30.0 & & \\
\hline 03AMBR01 & 18.5 & 81.5 & & 100.0 & & \\
\hline 03AMBR02 & 5.0 & 95.0 & & 100.0 & & \\
\hline 03TENN01 & 20.5 & 79.5 & 7.7 & 92.3 & & \\
\hline 03TENN02 & 29.4 & 70.6 & 5.0 & 95.0 & & \\
\hline 04NERA01 & 23.8 & 76.2 & & 100.0 & & \\
\hline 04RAPE01 & 32.9 & 67.1 & 60.0 & 40.0 & & \\
\hline 04TORS01 & 1.5 & 98.5 & & 100.0 & & \\
\hline 04USSI01 & 84.8 & 15.2 & 100.0 & & & \\
\hline 04USSI02 & 80.0 & 20.0 & 100.0 & & & \\
\hline 05CESA01 & 100.0 & & 100.0 & & & \\
\hline 05CESA02 & 92.9 & 7.1 & 100.0 & & & \\
\hline $05 \mathrm{CINI} 01$ & 97.7 & 2.3 & 100.0 & & & \\
\hline 05CINI02 & 98.2 & 1.8 & 100.0 & & & \\
\hline 06ACQU01 & 18.2 & 81.8 & 10.0 & 90.0 & & \\
\hline 06FIAS02 & 30.0 & 70.0 & 28.6 & 71.4 & & \\
\hline 06FIAS03 & 55.3 & 44.7 & 31.6 & 26.3 & 31.6 & 10.5 \\
\hline 06RIOS01 & 36.1 & 63.9 & 35.0 & 30.0 & & 35.0 \\
\hline 07CAMP01 & 27.1 & 72.9 & 30.0 & 55.0 & 15.0 & \\
\hline 07POTE01 & 100.0 & & 100.0 & & & \\
\hline 07SCAR02 & 91.7 & 8.3 & 72.7 & 18.2 & & 9.1 \\
\hline
\end{tabular}


specimens were considered "mild introgressed", as the percentages of Atlantic variants ranged from $10 \%$ to $90 \%$ for the mtDNA and from $20 \%$ to $80 \%$ for the $L D H-C 1$ * locus. The low introgressed populations belonged to the Ambro, Tenna and Torsa rivers (609 specimens in total). A total of 324 specimens belonged to the severe introgressed populations; all the remaining specimens belonged to the mild introgressed populations.

In general, the native populations were characterized by smaller sizes and lower longevity than the alien populations (Tab. 3). Higher population density and adult density values characterized the Mediterranean populations in comparison with the alien ones (Tab. 3, Fig. S1). For both groups the same average value of legal size specimens density was found. The differences were statistically significant at the $t$-test analysis only for the population density, adult density, mean weight and mean total length.

The results showed that the Mediterranean trout populations living in the fishing areas were characterized

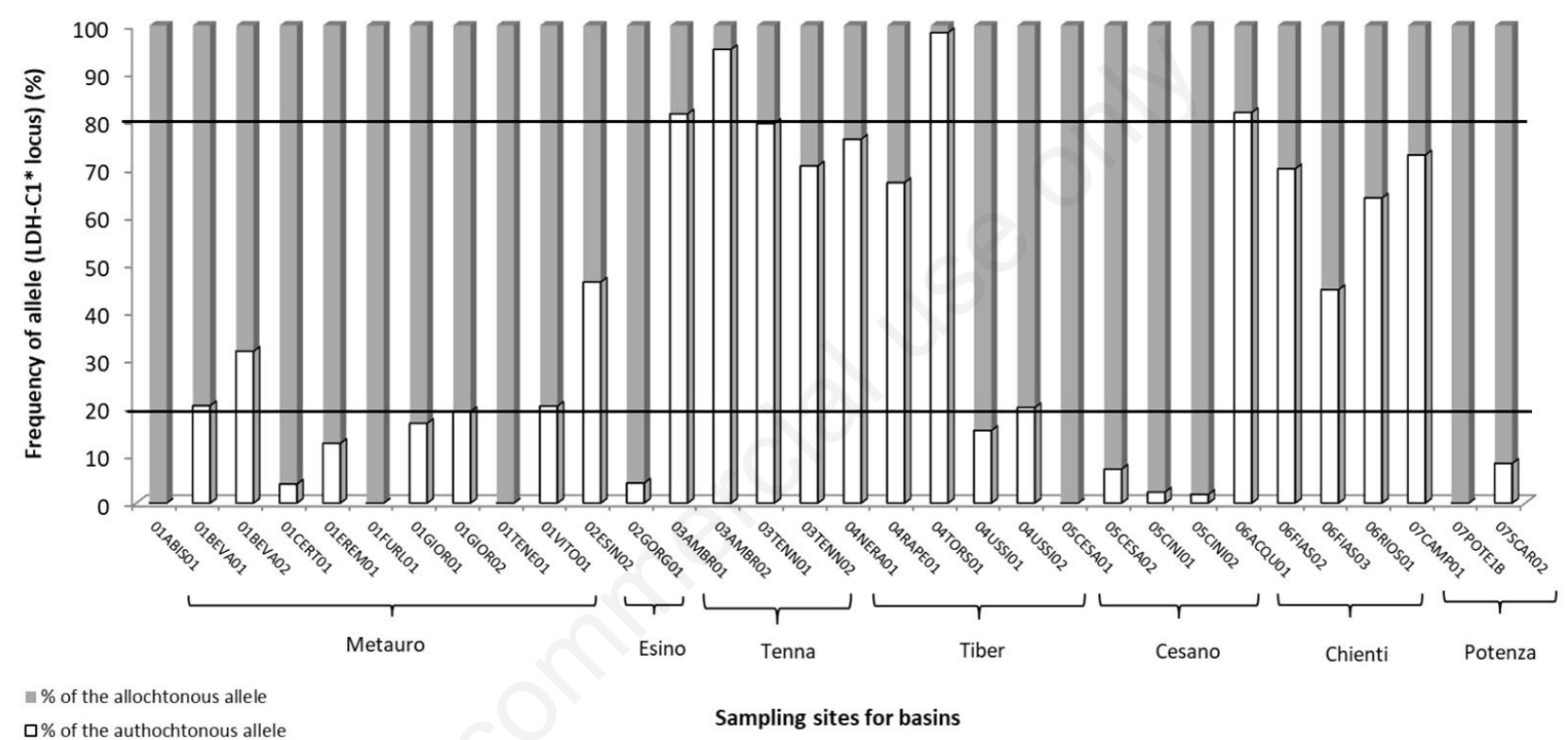

Fig. 2. Genetic introgression measured as the percentage of the diagnostic LDH-C $1 * 90$ allele, within each basin.

Tab. 3. $t$-test analysis: comparison of demographic parameters for Mediterranean trout and Atlantic trout populations. $\mathrm{P}$ values $<0.05$ is in bold.

\begin{tabular}{|c|c|c|c|c|}
\hline & Mediterranean trout & Atlantic trout & $\mathrm{t}$ & $\mathbf{P}$ \\
\hline $\mathrm{N}$ specimens & 609 & 324 & - & - \\
\hline TL range $(\mathrm{cm})$ & $3.0-31.0$ & $3.0-38.4$ & - & - \\
\hline $\mathrm{TL}$ mean $\pm \mathrm{SE}$ & $11.89 \pm 0.23$ & $15.28 \pm 0.36$ & 8.34 & 0.001 \\
\hline W range $(\mathrm{g})$ & $1.0-335.0$ & $0.8-612.0$ & - & - \\
\hline $\mathrm{W}(\mathrm{g})$ mean $\pm \mathrm{SE}$ & $34.59 \pm 1.86$ & $62.09 \pm 4.78$ & 6.06 & 0.001 \\
\hline Age classes range (years) & $0^{+}-6^{+}$ & $0^{+}-8^{+}$ & - & - \\
\hline Density (ind $/ \mathrm{m}^{2}$ ) mean $\pm \mathrm{SE}$ & $0.30 \pm 0.13$ & $0.09 \pm 0.02$ & 2.08 & 0.049 \\
\hline Standing crop $\left(\mathrm{g} / \mathrm{m}^{2}\right)$ mean $\pm \mathrm{SE}$ & $8.04 \pm 1.95$ & $5.43 \pm 0.99$ & 1.32 & 0.199 \\
\hline YOY density (ind $/ \mathrm{m}^{2}$ ) mean $\pm \mathrm{SE}$ & $0.18 \pm 0.11$ & $0.03 \pm 0.01$ & 1.67 & 0.108 \\
\hline Adult density $\left(\right.$ ind $\left./ \mathrm{m}^{2}\right)$ mean $\pm \mathrm{SE}$ & $0.05 \pm 0.01$ & $0.02 \pm 0.01$ & 2.55 & 0.017 \\
\hline $\mathrm{PSD}$ index mean $\pm \mathrm{SD}$ & $12.50 \pm 3.41$ & $29.34 \pm 6.72$ & 1.88 & 0.073 \\
\hline $\mathrm{Wr}$ mean $\pm \mathrm{SE}$ & $94.93 \pm 1.64$ & $96.13 \pm 1.51$ & 0.51 & 0.617 \\
\hline Legal size specimens density mean \pm SE & $0.01 \pm 0.00$ & $0.01 \pm 0.00$ & 0.76 & 0.456 \\
\hline
\end{tabular}


by higher values of total density, YOY density and $\mathrm{W}_{\mathrm{r}}$, while the no-fishing areas were characterized by higher standing crop, adult density, specimens of legal size density and PSD index (Tab. 4, Fig. S2); only for specimens of legal size density $(\mathrm{t}=2.57, \mathrm{P}=0.03)$, $\mathrm{PSD}$ $(\mathrm{t}=2.94, \mathrm{P}=0.02)$ and relative weight $(\mathrm{t}=2.64, \mathrm{P}=0.03)$ the results were statistically significant at the t-test analysis.

\section{Relationship among environmental, demographic and genetic parameters}

In the Canonical Correspondence Analysis the Monte Carlo test showed statistically significant results for all canonical axes $(\mathrm{F}=1.569 ; \mathrm{P}=0.017$; total inertia $=0.141)$. The first axis, which explained $53.60 \%$ of the overall variability ( $\mathrm{F}=12.597 ; \mathrm{P}=0.049)$, represented the genetic introgression gradient of the analyzed populations. Results showed that the Axis 1 was inversely correlated with altitude and permeability of the soil, while a positive correlation with conductivity and $\mathrm{SO}_{4}$ was observed (Tab. 1). The percentage of the alien genome is directly related to axis 1 , while the opposite result has been shown for the native genome. Although the second axis was less informative (26.20\% of total variance) it well described the relationship between the demographic parameters and the longitudinal gradient of the rivers. Average slope, $\Delta$ flow rate, permeability, canopy cover, water temperature, $\mathrm{pH}$, dissolved oxygen and $\mathrm{PPO}_{4}$ were significantly correlated with the second axis. High values of some demographic parameters (adult densities, legal size specimen density, standing crop) were associated with higher temperatures, larger watershed areas, higher distance to water source, high presence of canopy cover and shaded surfaces, low $\mathrm{pH}$ conditions and higher content of dissolved salts (phosphates and nitrates). An inverse correlation was observed between the same demographic parameters and $\mathrm{W}_{\mathrm{r}}$ (Fig. 3). The Atlantic populations were closely related to higher flow rates and poor water quality, as results by higher values of COD, conductivity and dissolved salts such as chlorides and sulphates; the presence of highly introgressed populations was also associated with a high value of the PSD. By contrast, native trout populations were linked to higher altitudes, higher average slopes, high soil permeability, and sites characterized by high levels of dissolved oxygen.

\section{DISCUSSION}

The results obtained in the present research allowed us to detect the presence of three residual Mediterranean trout populations with a high degree of genetic integrity in the Apennine area. These populations play a crucial role in the biodiversity conservation, as well as represent an opportunity to deepen the knowledge of ecological aspects, and can be used for native trout recovery projects.

The collection of genetic, demographic and environmental data allowed us to highlight the importance of environmental factors in evaluating the dynamics of genetic introgression into native salmonid populations, a crucial aspect for the conservation of the Mediterranean trout (Fausch et al., 2009; Muhlfeld et al., 2009; Marie et al., 2012). In particular, the results of the present research seem to confirm the key role played by the main geological characteristics of the central Apennines in shaping the introgression levels observed in the wild trout populations (Splendiani et al., 2013). In fact, the CCA results highlighted that in the central Apennine streams the demographic characteristics of wild trout populations, in terms of YOY and population density, are closely related with soil permeability and good water quality, while they are inversely related to the levels of introgression and fluctuations of river discharge. Among all the environmental parameters, the water quality and, indirectly, the flow rate seem to play a crucial role for conservation and management of native populations. As a result of climate change, an increasing unpredictability in water flows of the Mediterranean rivers is expected in the future. As reported by Ayllón et al. (2016), cold-water fish such as salmonids may be affected more than other

Tab. 4. $t$-test analysis: comparison of demographic parameters, body condition and PSD among fishing and no-fishing areas for Mediterranean trout populations. $\mathrm{P}$ values $<0.05$ is in bold.

\begin{tabular}{lcccc} 
& $\begin{array}{c}\text { No-fishing areas } \\
(\text { mean } \pm \text { SE) }\end{array}$ & \multicolumn{2}{c}{$\begin{array}{c}\text { Fishing areas } \\
(\text { mean } \pm \text { SE) }\end{array}$} \\
Population density $\left(\mathrm{ind} / \mathrm{m}^{2}\right)$ & $0.20 \pm 0.07$ & $0.37 \pm 0.21$ & 0.76 \\
\hline Standing crop $\left(\mathrm{g} / \mathrm{m}^{2}\right)$ & $9.14 \pm 2.60$ & $7.31 \pm 2.90$ & 0.22 \\
\hline YOY density $\left(\mathrm{ind} / \mathrm{m}^{2}\right)$ & $0.08 \pm 0.05$ & $0.25 \pm 0.19$ & 1.73 \\
\hline Adult density $\left(\mathrm{ind} / \mathrm{m}^{2}\right)$ & $0.07 \pm 0.01$ & $0.04 \pm 0.02$ & 0.025 \\
\hline Specimens of legal size $(\mathrm{TL}>22 \mathrm{~cm})$ density $\left(\mathrm{ind} / \mathrm{m}^{2}\right)$ & $0.03 \pm 0.01$ & $0.01 \pm 0.00$ & 0.999 \\
\hline Wr (units) & $90.30 \pm 2.61$ & $97.25 \pm 1.36$ & $\mathbf{0 . 0 3 0}$ \\
\hline PSD index (units) & $21.54 \pm 5.50$ & $6.48 \pm 2.15$ & $\mathbf{0 . 0 3 0}$ \\
\hline
\end{tabular}


species by these effects of global warming, with an evident reduction in abundances in terms of density and biomass, and a water quality worsening, due to the higher concentration of pollutants. These effects can be much more pronounced when combined with other anthropogenic pressures, such as water abstraction and non-compliance with the Minimum Ecological Flow rules (Palmer et al., 2009; Hermoso and Clavero, 2011).

About adult density, legal size density and standing crop the main variables pointing forward descriptors were water temperature and $\mathrm{PPO}_{4}$; these parameters, and, to a less extent, canopy cover, were nearly orthogonal to the "genetic axis", suggesting their full independence from the genetic origin of trout, and their role in describing the natural variation along the "longitudinal river axis". These results confirmed that high values of abundance in trout populations, especially in terms of larger specimens, were associated with the longitudinal gradient of the rivers and the increase of their productivity, with a usual trend for temperate rivers (Vannote et al., 1980; Cummins et al., 1984; Mann and Penczak, 1986; Gibson, 1988).

The results of the CCA analysis also highlighted the influence of the stocking activities on the genetic integrity of native trout populations in the study area. In fact, it was found the existence of a direct relationship between the genetic integrity of Mediterranean trout populations and the altitude: the Mediterranean trout populations with the lowest values of introgression were located in remote areas at high altitude, where, because

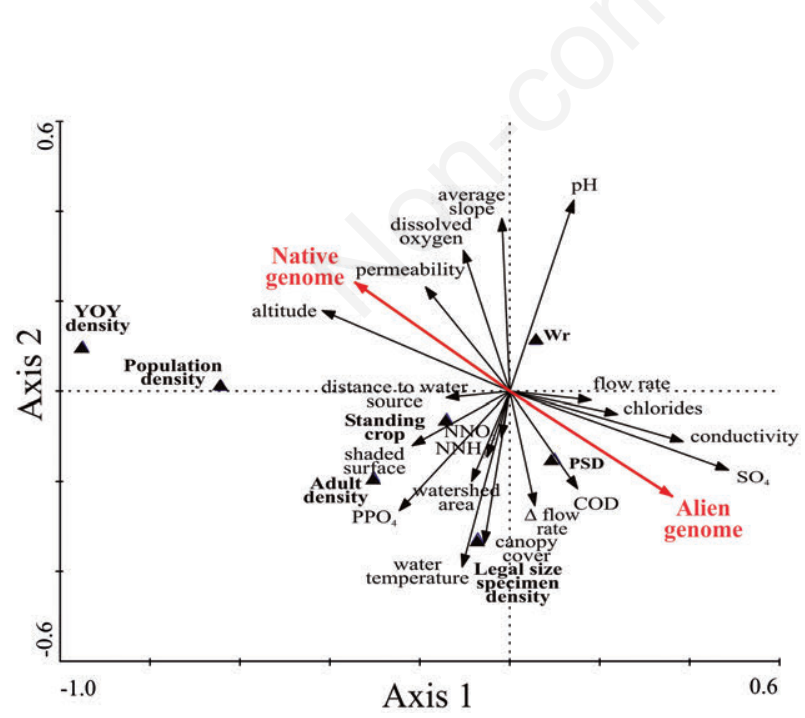

Fig. 3. Results of CCA analysis: biplot of the environmental variables and the genetic and demographic parameters. Eigenvalues of axis 1 and 2 were 0.04 and 0.02 respectively. The first two axes explained $79.80 \%$ of total variance. The length of the arrow is proportional to the rate of change: a long arrow indicates a large change and that change is strongly correlated with the ordination axes. of the inaccessibility, it is unlikely that restocking activities have occurred in the past (Berrebi et al., 2000). The presence of the non-native trout was associated with poor water quality, as showed by the direct correlation with the dissolved salts and the COD. However, should be taken into account the different rate of stocking along the longitudinal axis of the river, which could have had an influence on the relationships between environmental variables and the genetic integrity of trout populations observed in the present study. Atlantic stocks could have been introduced preferentially in more accessible, lowland river stretches, where fishing pressure is more relevant and where anthropic activities, leading to water quality worsening, are likely more concentrated. A previous study suggested that the river accessibility could affect the introgression levels within native trout populations (Splendiani et al., 2016). Moreover, alien populations were often characterized by an imbalanced age structure, with the presence of many large size specimens, as showed by the high PSD values: these results highlighted a direct consequence of the stocking activities carried out often in marginal environments, using adults of legal size for a mere put and take fishing purpose (Splendiani et al., 2006).

According to previous researches carried out in the Tiber river basin (central Italy) (Carosi et al., 2005, 2015), the more specialized reophilic species, as the Mediterranean trout, colonized the most mountainous river stretches, characterized by good water quality, high altitude, and high average slope. These species were gradually replaced, along the longitudinal gradient of the rivers, by the most tolerant species, as the Atlantic trout, which coming from rivers with different environmental characteristics from those of the Apennines, is better adapted to colonize the downstream reaches, even if further analyses based on the micro-habitats' analysis will be required to confirm this hypothesis.

The mean standing crop values observed in the present research can be considered in the standard range for the trout populations (Coles et al., 1988), considering the small size and the limited productivity that generally characterized the watercourses analyzed, also typical of most Mediterranean rivers (Nicola et al., 2009; Lorenzoni et al., 2009).

According to Araguas et al. (2017), the genetic identification of the populations with a high degree of genetic integrity and the establishment of "genetic refuges" is not sufficient to ensure the recovery of native trout populations. Additional concrete conservation actions, based on the ecological analysis results, should be put in practice for the recovery of the native genetic pools. In particular the actions recommended are: i) eradication programs and re-introduction of the Mediterranean trout in sites in which alien populations were detected, carrying out 
supplementing action with native stocks; ii) selection of the suitable sites as source of native trout for the production of native stocks; iii) supportive breeding actions in favor of partially introgressed populations. In the present study, based on the genetic make-up observed in wild samples the concrete conservation actions were organized as follows: i) six sites characterized exclusively by alien trout were selected for electrofishing eradication and successive reintroduction of native trout, ii) four sites, characterized by moderate levels of introgression, were selected for supportive breeding activities and iii) seven sites hosting "pure" or almost "pure" Mediterranean trout were selected as source of fishes to keep in captivity to create stocks of breeders of native origin. Noteworthy, during the mating phases and during the supplemental activities the information concerning the local genetic structure of native trout were used to design local management units (Caputo et al., 2015). This precaution was aimed to reduce the risks of genetic homogenization connected with supplementing programs (Fernández-Cebrián et al., 2014).

The Mediterranean populations were characterized by high values of population densities. The poor body condition characterizing the populations living in protected areas could be related to the intraspecific competition for feeding territories that could be emphasized by the high density values recorded in the sampling sites (Nordwall et al., 2001; Ayllón et al., 2009; Elliot, 2009).

The Mediterranean trout populations were also characterized by higher adult density values than the alien populations; this result, combined with the high population densities, supported the hypothesis that the Mediterranean trout is resilient to introgression phenomena. Within a concrete conservation strategy, the high adult density of Mediterranean trout make these populations able to tolerate the removal of a reduced number of adults per year for the production of pure juvenile trout in hatchery (for re-introduction or supportive breeding purposes).

The data collected are also the indispensable premise for the adoption of other necessary management strategies for conservation of the Apennine trout in central Italy. Such strategies could involve the establishment of protected areas in which fishing is forbidden, even if that may not be easily accepted by sport fishermen (Danylchuk and Cooke, 2010), generally opposed at loss of recreational fishing opportunities (Salz and Loomis, 2005; Sutton and Tobin, 2009). An important aspect of a fish conservation project is the involvement of local sport fishing community to increase their awareness of the problem and ease their acceptance of more restricting fishery and fish management rules (Danylchuk and Cooke, 2010). Also in our case, in the fishing areas a reduction in the abundance of Mediterranean trout populations and, above all, an imbalance in their structure were observed. As many studies had shown, fishing has the effect of an additional mortality to natural factors, that focuses especially on older age specimens (Ricker, 1975; Cooke and Cowx, 2004; Lewin et al., 2006; Lorenzoni et al., 2009).

As an alternative to the total ban of fishing activities, it is worth considering the possibility of allowing more sustainable fishing methods. For example, especially in protected areas depressed from the economic perspective, the catch and release method could provide a good compromise between the needs of biodiversity conservation and the socio-economic benefits that recreational fishing can ensure (Arlinghaus et al., 2002; Casselman, 2005; Cooke and Schramm, 2007; Donaldson et al., 2008; Lorenzoni et al., 2009).

\section{CONCLUSIONS}

The identification of alien and native trout populations in the Apennine area, combined with the assessment of their demographic features, is essential to underpin concrete conservation actions, as brown trout removal activities and Mediterranean trout re-introduction. For the first time in the present study, the analysis of original data collected in the field fully confirmed the finding of previous studies (Splendiani 2013, 2016), based on data reported in the literature, that is the key role played by the geological characteristics in shaping the introgression pattern of native trout populations, while the recovery of the environmental quality is decisive in the development of management strategies aimed at their conservation. Moreover, in order to guarantee stable hydrological conditions, and consequently ensure the environmental conditions suitable to the presence of the Mediterranean trout, the maintaining of the Minimum Ecological Flows should be considered in conservation programs for native trout from the Mediterranean area. Further analysis focused on the microhabitat preferences of the species are certainly needed.

\section{ACKNOWLEDGMENTS}

This work was supported by Life+ TROUT Project (LIFE12 NAT/IT/0000940) for the recovery and conservation of Mediterranean trout in the central Apennines (Italy), within the framework of the European Commission' Life Projects. The authors wish to thank all of the people who joined in the field activities during the project.

\section{REFERENCES}

Almodóvar A, Nicola GG, Ayllón D, Elvira B, 2012. Global warming threatens the persistence of Mediterranean brown trout. Glob. Change Biol. 18:1549-1560. 
Almodóvar A, Nicola GG, Elvira B, García-Marín, JL, 2006. Introgression variability among Iberian brown trout Evolutionary Significant Units: the influence of local management and environmental features. Freshwater Biol. 51:1175-1187.

Angeli V, Bicchi A, Carosi A, Spigonardi MP, Pedicillo G, Lorenzoni M, 2009. Proposed standard weight equations for brown trout (Salmo trutta Linnaeus, 1758) and Barbus tyberinus Bonaparte, 1839 in the river Tiber basin (Italy). Electron. J. Ichthyol. 2:21-29.

Aparicio E, Vargas MJ, Olmo JM, de Sostoa A, 2000. Decline of native freshwater fishes in a Mediterranean watershed on the Iberian Peninsula: a quantitative assessment. Environ. Biol. Fishes 59:11-19.

APAT CNR IRSA, 2003. [Metodi analitici per le acque]. [Manual in Italian]. IGER, Rome: 1153 pp. Available fron: http://www.isprambiente.gov.it/it/pubblicazioni/manuali-elinee-guida/metodi-analitici-per-le-acque

Apostolidis AP, Triantaphillidis C, Kouvatsi A, Economidis PS, 1997. Mitochondrial DNA sequence variation and phylogeography among Salmo trutta L. (Greek brown trout) populations. Mol. Ecol. 6:531-542.

Araguas RM, Vera M, Aparicio E, Sanz N, Fernandez-Cebri R, Marchante C, García-Marín JL, 2017. Current status of the brown trout (Salmo trutta) populations within eastern Pyrenees genetic refuges. Ecol. Freshw. Fish 26:120-132.

Arlinghaus R, Mehner T, Cowx IG, 2002. Reconciling traditional inland fisheries management and sustainability in industrialized countries, with emphasis on Europe. Fish and Fisheries 3:261-316.

Aurelle D, Berrebi P, 2001. Genetic structure of brown trout (Salmo trutta, L.) populations from south-western France: data from mitochondrial control region variability. Mol. Ecol. 10:1551-1561.

Ayllón D, Almodóvar A, Nicola GG, Elvira B, 2009. Modelling brown trout spatial requirements through physical habitat simulations. River Res. Appl. 26:1090-1102.

Ayllón D, Railsback SF, Vincenzi S, Groenevelda J, Almodóvar A, Grimma V, 2016. InSTREAM-Gen: Modelling eco-evolutionary dynamics of trout populations under anthropogenic environmental change. Ecol. Modell. 326:36-53.

Bagenal TB, 1978. Fish production in fresh waters. Blackwell, Oxford: $250 \mathrm{pp}$.

Benbouza H, Jacquemin JM, Baudoin JP, Mergeai G, 2006. Optimization of reliable, fast, cheap and sensitive silver staining method to detect SSR markers in polyacrylamide gels. Biotechnol. Agron. Soc. Environ. 10:77-81.

Bernatchez L, 2001. The evolutionary history of brown trout (Salmo trutta L.) inferred from phylogeographic, nested clade, and mismatch analyses of mitochondrial DNA variation. Evolution 55:351-379.

Bernatchez L, Danzmann RG, 1993. Congruence in control region sequence and restriction-site variation in mitochondrial DNA of brook charr (Salvelinus fontanilis Mitchill). Mol. Biol. Evol. 10:1002-1014.

Berrebi P, Poteaux C, Fissier M, Cattaneo Berrebi G, 2000. Stocking impact and allozyme diversity in brown trout from Mediterranean southern France. J. Fish Biol. 56:949-960.

Blackwell BG, Brown ML, Willis DW, 2000. Relative Weight
(Wr) status and current use in fisheries assessment and management. Rev. Fisher. Sci. 8:1-44.

Britton JR, Cowx IG, Peirson G, 2004. Sources of error in the ageing of stocked cyprinids. Fisheries Manag. Ecol. 11: 415-417.

Brown ML, Austen DJ, 1996. Data management and statistical techniques. In: B.R. Murphy and D.W. Willis (eds.), Fisheries Techniques. American Fisheries Society.

Caputo Barucchi V, Carosi A, Giovannotti M, La Porta G, Splendiani A, Lorenzoni M, 2015. Life+ Trout Project (LIFE12 NAT/IT/0000940) for the recovery and conservation of Mediterranean trout (Salmo trutta complex) in the central Apennines (Italy). Front Mar Sci Conference Abstract: XV European Congress of Ichthyology. doi: 10.3389/conf.fmars.2015.03.00101.

Caputo V, Giovanotti M, Nisi Cerioni P, Caniglia ML, Splendiani A, 2004. Genetic diversity of brown trout (Salmo trutta L., 1758) in central Italy. J. Fish Biol. 65:403-418.

Carosi A, Ghetti L, Forconi A, Lorenzoni M, 2015. Fish community of the river Tiber basin (Umbria-Italy): temporal changes and possible threats to native biodiversity. Knowl. Manag. Aquat. Ecosyst. 416:22.

Carosi A, Pedicillo G, Bicchi A, Angeli V, Ghetti L, Lorenzoni M, 2005. [Distribuzione e abbondanza delle popolazioni di trota fario (Salmo trutta L.) nel bacino del fiume Tevere in Umbria].[Article in Italian]. 15th Meeting of the Italian Society of Ecology, Turin, Italy.

Casselman SJ, 2005. Catch-and-release angling: a review with guidelines for proper fish handling practices. Ontario Ministry of Natural Resources, Peterborough: 26 pp.

Clavero M, Hermoso V, Kark S, Levin N, 2010. Geographical linkages between threats and imperilment in freshwater fish in the Mediterranean Basin. Divers. Distrib 16:744-754.

Coles TF, Extence CA, Bates AJ, Oglanby GT, Mason C, 1988. Surveing the entire ecosystem. Pol. Arch. Hydrobiol. 35:563-575.

Cooke SJ, Cowx IG, 2004. The role of recreational fisheries in global fish crises. BioScience 54:857-859.

Cooke SJ, Schramm HL, 2007. Catch-and-release science and its application to conservation and management of recreational fisheries. Fish. Manag. Ecol. 14:73-79.

Cortey M, Pla C, García-Marín JL, 2004. Historical biogeography of Mediterranean trout. Mol. Phylogenet. Evol. 33:831-844.

Cummins KW, Minshall GW, Sedell JR, Cushing CE, Petersen RC, 1984. Stream ecosystem theory. Verh. Internat. Verein Limnol. 22:1818-1827.

Danylchuk AJ, Cooke SJ, 2010. Engaging the recreational angling community to implement and manage aquatic protected areas. Conserv. Biol. 25:458-464.

Donaldson MR, Arlinghaus R, Hanson KC, Cooke SJ, 2008. Enhancing catch and release science with biotelemetry. Fish Fish.9:79-105.

Dove P, Susnik S, Snoj A, 2004. Experience from Lipizzan horse and salmonid species endemic to the Adriatic river system. Examples for the application of molecular markers for preservation of biodiversity and management of animalgenetic resources. J. Biotechnol. 113:43-53.

Elliot JM, 1994. Quantitative ecology and the brown trout. Oxford University press, Oxford: 286 pp. 
Elliot JM, 2009. Validation and implications of a growth model for brown trout, Salmo trutta, using long-term data from a small stream in north-west England. Freshwater Biol. 54:2263-2275.

Fausch KD, Rieman BE, Dunham JB, Young MK, Peterson DP, 2009. Invasion versus isolation: Trade-offs in managing native salmonids with barriers to upstream movement. Conserv. Biol.23:859-870.

Fernández-Cebrián R, Araguas RM, Sanz N, García-Marín JL, 2014. Genetic risks of supplementing trout populations with native stocks: a simulation case study from current Pyrenean populations. Can. J. Fish Aquat. Sci. 71:1243-1255.

Filipe F, Markovic D, Pletterbauer F, 2013. Forecasting fish distribution along stream networks: brown trout (Salmo trutta) in Europe. Divers. Distrib. 19:1059-1071.

Gabelhouse DW, 1984. A length-categorization system to assess fish stocks. N. Am. J. Fish. Manage.t 4:273-285.

García-Marín JL, Sanz N, Pla C, 1998. Proportions of native and introduced brown trout in adjacent fished and unfished Spanish rivers. Conserv. Biol. 12:313-319.

García-Marín JL, Sanz N, Pla C, 1999. Erosion of the native genetic resources of brown trout in Spain. Ecol. Freshw. Fish. 8:151-158.

Gassner H, Tischler G, Wanzenbock J, 2003. Ecological integrity assessment of lakes using fish communities: suggestions of new metrics developed in two Austrian prealpine lakes. Int. Rev. Hydrobiol. 88:635-652.

Gibson RJ, 1988. Mechanism regulating specie composition, population structure, and production of stream salmonids: a review. Pol. Arch. Hydrobiol. 35:469-495.

Hermoso V, Clavero M, 2011. Threatening processes and conservation management of endemic freshwater fish in the Mediterranean basin: a review. Mar. Freshwater Res. 62: 244-254.

ISO 748:2007 Hydrometry - Measurement of liquid flow in open channels using current-meters or floats: $58 \mathrm{pp}$.

IUCN, 2018. The IUCN Red list of threatened species, ver. 2017-3. Accessed on: 15 June 2018.

Lammert M, Allan JD, 1999. Assessing biotic integrity of streams: Effects of scale in measuring the influence of land use/cover and habitat structure on fish and macroinvertebrates. Environ. Manage. 23:257-270.

Larios-López JE, Tierno de Figueroa JM, Galiana-García M, Gortázar J, Alonso C, 2015. Extended spawuning in brown trout (Salmo trutta) populations from the Southern Iberian Peninsula: the role of climate variability. J. Limnol. 74:1089.

Larkin MA, Blackshields G, Brown NP, Chenna R, McGettigan PA, McWilliam H, Valentin F, Wallace IM, Wilm A, Lopez R, Thompson JD, Gibson TJ, Higgins DG, 2007. ClustalWand Clustal X version 2.0. Bioinformatics 23:2947-2948.

Lewin WC, Arlinghaus R, Mehner T, 2006. A review of documented and potential biological impacts of recreational angling: insights for management and conservation. Rev. Fish. Sci.14:305-367.

Lorenzoni M, Barocco R, Carosi A, Giannetto D, Pompei L, 2014. [La fauna ittica dei corsi d'acqua appenninici in relazione alle variazioni del regime delle deposizioni umide].[Article in Italian]. Biologia Ambientale 28:67-73.

Lorenzoni M, Carosi A, Natali M, Pedicillo G, Viali P, 2009. [La pratica del Catch and Release per la gestione delle popolazioni ittiche nelle aree protette].[Article in Italian]. Atti SItE 32:127-131.

Lorenzoni M, Maio G, Nonnis Marzano F, 2004. [Stato attuale delle conoscenze sulle popolazioni autoctone di trota in Italia: necessità di un approccio integrato].[Article in Italian]. Quaderni ETP 33:1-12.

Mann RHK, Penczak T, 1986. Fish production in rivers: a review. Pol. Arch. Hydrobiol. 33:233-247.

Marie AD, Bernatchez L, Garant D, 2012. Environmental factors correlate with hybridization in stocked brook charr (Salvelinus fontinalis). Can. J. Fish Aquat. Sci. 69:1-10.

McMeel OM, Hoey EM, Ferguson A, 2001. Partial nucleotide sequences, and routine typing by polymerase chain reactionrestriction fragment length polymorphism, of the brown trout (Salmo trutta) lactate dehydrogenase, LDH-C1*90 and *100 alleles. Mol. Ecol. 10:29-34.

Mezzera M, Largiadèr CR, 2001. Evidence for selective angling of introduced trout and their hybrids in a stocked brown trout population. J. Fish Biol. 59:287-301.

Moran PAP, 1951. A mathematical theory of animal trapping. Biometrika 38:307-311.

Muhlfeld CC, McMahon TE, Boye, MC, Gresswell RE, 2009. Local habitat, watershed, and biotic factors influencing the spread of hybridization between native west slope cutthroat trout and introduced rainbow trout. T. Am. Fish Soc. 138:1036-1051.

Nicola GG, Almodóvar A, Elvira B, 2009. Influence of hydrologic attributes on brown trout recruitment in lowlatitude range margins. Oecologia 160:515-524.

Nonnis Marzano F, Corradi N, Papa R, Tagliavini J, Gandolfi $\mathrm{G}, 2003$. Molecular evidence for introgression and loss of genetic variability in Salmo (trutta) macrostigma as a result of massive restocking of Apennine populations (Northern and Central Italy). Environ. Biol. Fishes 68:349-356.

Nordwall F, Näslund I, Degerman E, 2001. Intercohort competition effects on survival, movement, and growth of brown trout (Salmo trutta) in Swedish streams. Can. J. Fish. Aquat. Sci. 58:2298-2308.

Palmer MA, Lettenmaier DP, LeRoy Poff N, Postel SL, Richter B, Warner R, 2009. Climate change and river ecosystems: Protection and adaptation options. Environ. Manage. 44:1053-1068.

Pedicillo G, Carosi A, Ghetti L, Lorenzoni M, 2010. Population size structure indices and growth standards for Salmo (trutta) trutta Linnaeus, 1758 in Central Italy. Knowl. Manag. Aquat. Ecosyst. 399:02.

Raymond M, Rousset F, 1995. GENEPOP (Version 1.2): a population genetics software for exact tests and ecumenicism. J. Heredity 86:248-249.

Ricker WE, 1975. Computation and interpretation of biological statistics of fish populations. J. Fish. Res. Board Can. 191:381-39.

Salz R, Loomis DK, 2005. Recreation specialization and anglers' attitudes towards restricted fishing areas. Human Dimen. Wildlife 10:187-199.

Sanz N, Cortey M, Pla C, García-Marín JL, 2006. Hatchery introgression blurs ancient hybridization between brown trout (Salmo trutta) lineages as indicated by complementary allozymes and mtDNA markers. Biol. Conserv. 130:278-289.

Seber GAF, Le Cren ED, 1967. Estimating population 
parameters from catches larges relative to the population. J. Anim. Ecol. 36:631-643.

Smith TA, Kraft CE, 2005. Stream fish assemblages in relation to landscape position and local habitat variables. Trans. Am. Fish. Soc. 134:430-440.

Solomon GW, Mawleb DJ, Duncan W, 2003. An integrated approach to salmonid management Author links open overlay panel. Fish. Res. 62:229-234.

Splendiani A, Giovannotti M, Nisi Cerioni P, Caniglia ML, Caputo V, 2006. Phylogeographic inference on the native brown trout mtDNA variation in central Italy. Ital. J. Zool. 73:179-189.

Splendiani A, Ruggeri P, Giovannotti M, Caputo Barucchi V, 2013. Role of environmental factors in the spread of domestic trout in Mediterranean streams. Freshwater Biol. 58:2089-2101.

Splendiani A, Ruggeri P, Giovannotti M, Pesaresi S, Occhipinti G, Fioravanti T, Lorenzoni M, Nisi Cerioni P, Caputo Barucchi V, 2016. Alien brown trout invasion of the Italian peninsula: the role of geological, climate and anthropogenic factors. Biol. Invasions 18:2029-2044.

Suarez J, Battista LM, Almodovar A, Machordom A, 2001. Evolution of the mithocondrial control region in Paleartic brown trout (Salmo trutta) populations: the biogeographical role of the Iberian Peninsula. Heredity 87:198-206.

Sutton SG, Tobin RC, 2009. Recreational fishers' attitudes towards the 2004 rezoning of the Great Barrier Reef Marine Park. Environ. Conserv.36:245-252.

ter Braak CJF, 1986. Canonical correspondence analysis: a new eigenvector technique for multivariate direct gradient analysis. Ecology 67:1167-1179.

Thompson JD, Higgins DG, Gibson TJ, 1994. CLUSTAL W: Improving the sensitivity of progressive multiple sequence alignment through sequence weighting, position-specific gap penalties and weight matrix choice. Nucleic Acids Res. 22:4673-4680.

Vadas RL, Orth DJ, 2000. Habitat use of fish communities in a Virginia stream system. Environ. Biol. Fishes 59:253-269.

Vannote RL, Minshall GW, Cummins KW, Sedell JR, Cushing CE, 1980. The River Continuum Concept. Can. J. Fish. Aquat. Sci. 37:130-137.

Weir BS, Cockerham CC, 1984. Estimating F-statistics for the analysis of population structure. Evolution 38:1358-1370.

Zippin C, 1956. An evaluation of the removal method of estimating animal populations. Biometrics 12:163-189. 